\title{
Pengembangan Media Komik untuk Meningkatkan Keterampilan Membaca Pemahaman Siswa Kelas IV SDN 41 Pekanbaru
}

\author{
Musnar Indra Daulay \& Nurmnalina \\ Universitas Pahlawan Tuanku Tambusai \\ musnarindradaulay@gmail.com,nurmalina1812@yahoo.com
}

\begin{abstract}
Abstrak
Penelitian ini bertujuan mengembangkan media komik yang layak dan efektif untuk meningkatkan keterampilan membaca pemahaman pada mata pelajaran bahasa Indonesia di kelas IV SD Negeri 41 Pekanbaru. Pada kegiatan pembelajaran bahasa Indonesia materi cerita anak aspek membaca pemahaman di kelas IV SDN 41 Pekanbaru masih menggunakan media teks bacaan sebagai satu-satunya acuan yang digunakan. Adapun solusi yang peneliti tawarkan yaitu mengembangkan media komik dalam pembelajaran. Jenis penelitian yang digunakan adalah penelitian pengembangan (Research and Development) yang mengadaptasi model ADDIE. Teknik pengumpulan data menggunakan observasi, tes pretest-postest, wawancara, dan angket. Teknik analisis data menggunakan analisis data kualitatif dan statistik deskriptif kuantitatif. Hasil penilaian ahli materi diperoleh rata-rata skor 4,56 (sangat layak). Hasil penilaian ahli media diperoleh rata-rata skor 4,59 (sangat layak). Hasil uji coba memperoleh kriteria sangat layak yaitu uji coba awal memperoleh rata-rata skor 4,2 (sangat layak), hasil uji coba utama memperoleh rata-rata skor 4,32 (sangat layak), dan hasil uji coba lapangan operasional memperoleh rata-rata skor 4,43 (sangat layak). Sedangkan hasil uji coba praktisi guru memperoleh rata-rata skor 4,74 (sangat layak). Guna mengetahui media komik dapat meningkatkan keterampilan membaca pemahaman siswa, digunakan soal pretest dan postest. Sesuai tabulasi data diketahui jumlah skor rata-rata nilai pretest sebesar 53,82, kemudian mengalami peningkatan pada skor rata-rata nilai postest sebesar 17,38 menjadi 71,20 . Perhitungan hasil peningkatan keterampilan membaca pemahaman siswa menggunakan Gain Score sebesar 0,376. kategori peningkatan sedang. Media akhir penelitian ini berupa komik untuk meningkatkan keterampilan membaca pemahaman siswa.
\end{abstract}

Kata kunci: Bahasa, Indonesia, Media, Komik

\section{Pendahuluan}

Bahasa Indonesia merupakan salah satu mata pelajaran penting di sekolah. Tujuan pembelajaran bahasa Indonesia adalah agar siswa memiliki pengetahuan berbahasa Indonesia yang baik dan benar serta mampu menghayatinya sesuai dengan situasi serta tingkat pengalaman siswa itu sendiri. Bahasa memainkan peran sentral dalam perkembangan intelektual, sosial dan emosional siswa dan mendukung keberhasilan belajar di semua bidang studi. Belajar bahasa akan memungkinkan orang untuk berkomunikasi satu sama lain, berbagi pengalaman, belajar satu sama lain, serta mampu meningkatkan keterampilan intelektual. Disamping itu, melalui membaca seseorang mendapat pengetahuan dan informasi dari berbagai penjuru dunia yang pada akhirnya akan dapat melahirkan generasi penerus bangsa yang cerdas, kreatif, dan kritis.

Kegiatan membaca selalu ada dalam setiap tema pembelajaran. Hal ini menunjukkan pentingnya penguasaan keterampilan membaca. Artinya, dengan memiliki keterampilan membaca pemahaman yang tinggi, siswa dapat memperoleh berbagai informasi dalam waktu yang relatif singkat. Membaca merupakan hal yang penting bagi pengembangan pengetahuan karena presentase transfer ilmu pengetahuan terbanyak dilakukan melalui membaca (Iskandarwassid, 2004:245). Membaca adalah keterampilan dasar bagi siswa dalam memperoleh pengetahuan 
dengan cara mendapatkan makna dari apa yang tertulis dalam teks. Tulisan menjadi aspek penting dalam membaca karena tanpa tulisan seseorang tidak dapat dikatakan sedang membaca.

Namun pada kenyataannya, belum semua siswa dapat mencapai tujuan tersebut. Banyak siswa dapat membaca secara lancar tetapi tidak memahami isi bahan bacaan tersebut. Data Progress in International Reading Literacy Study (PIRLS) yang meneliti siswa kelas IV SD menunjukkan bahwa prestasi membaca siswa Indonesia sangat rendah. Keterampilan membaca siswa Indonesia pada urutan ke 45 dari 49 negara yang diteliti. Skor Indonesia (405), atau berada di bawah skor rata-rata siswa Internasional sebesar 500, dengan standar deviasi 100. Penentuan sampel dilakukan berdasarkan tiga strata, yaitu jenis sekolah (SD/MI), status sekolah (negeri/swasta), dan lokasi sekolah (desa/kota). Tercatat sampel yang terpilih 4.950 siswa dari 170 SD/MI negeri dan swasta, serta berlokasi di desa dan kota. Hal ini menunjukkan bahwa keterampilan siswa kelas tinggi dalam membaca pemahaman masih rendah.

Kemampuan membaca siswa yang buruk disebabkan oleh beberapa faktor, antara lain model dan metode pembelajaran yang diterapkan guru masih tradisional, kurangnya motivasi dan minat siswa untuk mengikuti pembelajaran membaca serta media pembelajaran yang kurang memadai. Dalam pembelajaran membaca pemahaman, siswa biasanya disuguhkan dengan media pembelajaran berupa teks bacaan, setelah itu masingmasing diminta membacanya kemudian menjawab pertanyaan terkait isi bacaan yang diberikan. Akibatnya, siswa menjadi putus asa ketika diminta untuk membaca sendiri yang pada akhirnya siswa tersebut tidak memahami apa yang dibacanya.

Hasil pengamatan dan wawancara dengan guru Kelas IV SDN 41 Pekanbaru pada tanggal 14 Agustus 2020 dan 23 Agustus 2020, menunjukkan bahwa siswa kurang memahami suatu bacaan yang disajikan guru serta minat membaca sangat kurang. Saat pembelajaran bahasa Indonesia terutama kegiatan membaca pemahaman masih kurang berjalan maksimal. Saat mengikuti pembelajaran siswa terlihat kurang bersemangat, hal ini dikarenakan guru menggunakan metode pembelajaran yang beragam dalam mengajarkan pembelajaran membaca pemahaman namun media pembelajaran yang digunakan kurang memadai. Sehingga keterampilan membaca pemahaman siswa masih kurang bahkan bisa dikatakan masih memprihatinkan. Selanjutnya, berdasarkan hasil pretest yang dilakukan peneliti dalam pembelajaran membaca pemahaman, hanya $25 \%$ dari jumlah siswa yang mampu menjawab pertanyaan bacaan dengan tepat, $20 \%$ yang mampu meringkas bacaan dengan tepat, $29 \%$ yang mampu menceritakan kembali isi bacaan dengan kalimatnya sendiri, dan hanya 26\% yang mampu menyimpulkan isi bacaan, dengan nilai rata-rata hasil evaluasinya baru mencapai 53,82. Sedangkan data dari Kemendikbud nilai kriteria ketuntasan minimal (KKM) yang diharapkan dalam pembelajaran Bahasa Indonesia kelas IV aspek membaca adalah 73,33. Sehingga dapat dikatakan bahwa keterampilan membaca pemahaman siswa kelas IV SDN 41 Pekanbaru masih rendah dan dikategorikan low level dalam memahami bacaan karena hasilnya dibawah rata-rata skor masksimal. Oleh sebab itu, perlu adanya media pembelajaran yang efektif dalam membantu menumbuhkan minat dan kemauan siswa dalam membaca pemahaman dengan terampil. Media pembelajaran yang efektif merupakan media yang dapat membuat siswa mampu mengambil intisari makna suatu pengetahuan melalui kegiatan membaca.

Media pembelajaran berfungsi untuk mendukung pembelajaran siswa agar lebih mudah dan teratur, karena dapat memadukan antara kecerdasan afektif, kognitif, dan psikomotorik siswa. Sehingga dengan adanya media pembelajaran dapat membantu siswa untuk mempermudah penyampaian ilmu pengetahuan yang disampaikan guru kepada siswa, sehingga siswa menjadi 
termotivasi untuk belajar. Media pembelajaran dapat membantu siswa untuk meminimalisir kesalahan persepsi terhadap materi ajar yang disampaikan guru. Menurut teori Piaget, pemikiran anak usia sekolah dasar (7 - 11 tahun) masih berada pada tahap pemikiran operasional konkret (concrete operational thought). Hal itu dapat menjadi dasar penggunaan media pembelajaran yang inovatif dalam meningkatkan keterampilan membaca pemahaman.

Menurut survey dari Murti Bunanta yang merupakan ketua dari Kelompok Pecinta Bacaan Anak (KPBA) Indonesia, pada tahun 2012 90\% siswa sekolah dasar kelas tinggi lebih menyukai sebuah gambar penuh warna daripada tulisan yang penuh di dalam buku. Melihat permasalahan yang ada di lapangan, peneliti melihat perlu dikembangkannya media pembelajaran untuk meningkatkan keterampilan membaca pemahaman pada mata pelajaran bahasa Indonesia, karena media yang disajikan hanya tersedia teks bacaan. Sementara siswa kurang tertarik dengan membaca karena sulit untuk dipahami. Adapun solusi yang peneliti tawarkan yaitu mengembangkan media komik dalam pembelajaran. Hal ini sebagaimana dikemukakan Sudjana dan Rivai, (2009:6) bahwa penggunaan media komik dapat membangkitkan keterampilan membaca pemahaman siswa pada pembelajaran bahasa Indonesia.

\section{Kerangka Teori \\ Hakikat Pembelajaran Bahasa Indonesia di SD}

Pembelajaran bahasa Indonesia di SD diarahkan untuk meningkatkan kemampuan siswa untuk berkomunikasi dalam bahasa Indonesia dengan baik dan benar, baik secara lisan maupun tulisan serta dalam standar kompetensi mata pelajaran bahasa Indonesia diharapkan siswa dapat mengembangkan potensinya sesuai dengan kemampuan, kebutuhan, dan minatnya. Pembelajaran bahasa Indonesia dilaksanakan dengan prinsip humanisme, progresivisme, dan rekontruksivisme (Resmini, 2009: 29). Hakikat pembelajaran bahasa Indonesia di SD merupakan upaya membantu peserta didik mengenal dirinya, budayanya dan budaya orang lain, mengemukakan gagasan, dan perasaan, berpartisipasi dalam masyarakat yang menggunakan bahasa tersebut, serta mengemukakan kemampuan analitis dan imaginatif dalam dirinya. Adapun Ruang lingkup mata pelajaran bahasa Indonesia mencakup komponen kemampuan berbahasa dan kemampuan bersastra yang meliputi (Depdiknas, 2006: 18):

a) Mendengarkan, seperti mendengarkan berita, petunjuk, pengumuman, perintah, dan bunyi atau suara, bunyi bahasa lagu, kaset, pesan, penjelasan, laporan, ceramah, khotbah, pidato, pembicaraan nara sumber, dialog atau percakapan, pengumuman serta perintah yang di dengar dengan memberikan respon secara tepat serta mengapresiasi sastra berupa dongeng, cerita anak-anak, cerita rakyat, cerita binatang, puisi anak, syair lagu, pantun dan menonton drama anak.

b) Berbicara, seperti mengungkapkan gagasan dan perasaan, menyampaikan sambutan, dialog, pesan, pengalaman, suatu proses, menceritakan diri sendiri, teman, keluarga, masyarakat, benda, tanaman, binatang, gambar tunggal, gambar seri, kegiatan sehari-hari, peristiwa, tokohkesukaan/ketidaksukaan, kegemaran, peraturan, tata petunjuk, dan laporan, serta mengapresiasi dan berekspresi sastra melalui kegiatan menuliskan hasil sastra berupa dongeng cerita anak-anak, cerita rakyat, cerita binatang, puisi anak, syair lagu, pantun, dan drama anak.

c) Membaca, seperti membaca huruf, suku kata, kalimat, paragraf, berbagai teks bacaan, denah, petunjuk, tata tertib, pengumuman, kamus, ensiklopedi, serta mengapresiasi dan berekspresi, sastra melalui kegiatan membaca hasil sastra berupa dongeng, cerita anakanak, cerita rakyat, cerita binatang, puisi anak, syair lagu, pantun, dan drama anak. 
d) Menulis, seperti menulis karangan naratif, dan normatif dengan tulisan rapi dan jelas dengan memperhatikan tujuan dan ragam pembaca, pemakaian ejaan dan tanda baca, dan kosa kata yang tepat dengan menggunakan kalimat tunggal dan kalimat majemuk, serta mengapresiasi dan berekspresi sastra melalui kegiatan menulis hasil sastra berupa cerita dan puisi.

Berdasarkan ruang lingkup pembelajaran bahasa Indonesia di atas, maka pembelajaran bahasa Indonesia mengarah kepada peningkatan kemampuan berkomunikasi, karena keempat kemampuan berbahasa tersebut saling berkaitan dan memiliki peranan penting dalam berkomunikasi baik secara lisan maupun tulisan. Media yang dibuat mengarah kepada kemampuan berbahasa membaca, yang berfokus kepada peningkatan keterampilan membaca pemahaman pada materi cerita anak pada mata pelajaran bahasa Indonesia kelas IV.

\section{Keterampilan Membaca Pemahaman}

Membaca pemahaman merupakan keterampilan membaca yang berada pada urutan yang lebih tinggi. Membaca pemahaman adalah membaca secara kognitif (membaca untuk memahami). Pada membaca pemahaman, pembaca dituntut mampu memahami isi bacaan (Dalman, 2013:87). Artinya pada saat membaca seseorang melakukan proses penggalian pesan dari teks. Kemudian dengan berinteraksi dengan makna yang terdapat di dalam teks tersebut, pembaca membuat dan menguji hipotesis. Hasil dari pengujian hipotesis tersebut dapat dijadikan dasar untuk menarik kesimpulan mengenai pesan yang disampaikan oleh penulis (Slamet, 2003: 78). Jadi, dapat disimpulkan bahwa membaca pemahaman pada hakikatnya adalah suatu kegiatan untuk memperoleh informasi bacaan yang baik yang tersirat maupun tersurat dalam bentuk pemahaman dan kemampuan seseorang dalam mengkonstruksi pesan yang terdapat pada teks yang dibaca agar mengerti ide pokok, detail penting, dan seluruh pengertian serta mengingat bahan yang dibacanya. Adapun prinsip-prinsip yang paling mempengaruhi pemahaman membaca sebagaimana dikemukakan Rahim. (2008) adalah: (a) Pemahaman merupakan proses konstruktivis sosial; (b) Keseimbangan kemahiraksaraan adalah kerangka kerja kurikulum yang membantu perkembangan pemhaman; (c) Guru membaca yang profesional (unggul) mempengaruhi belajar siswa; (d) Pembaca yang baik memegang peranan yang strategis dan berperan aktif dalam proses membaca; (e) Membaca hendaknya terjadi dalam konteks yang bermakna; (f) Siswa menemukan manfaat membaca yang berasal dari berbagai teks pada berbagai tingkat kelas; (g) Perkembangan kosakota dan pembelajaran mempengaruhi pemahaman membaca; (h) Pengikutsertaan adalah suatu faktor kunci pada proses pemahaman; (i) Strategi dan keterampilan membaca bisa diajarkan; dan (j) Asesmen yang dinamis menginformasikan pembelajaran membaca pemahaman.

Berdasarkan prinsip membaca pemahaman di atas maka peranan guru, sangatlah besar dalam mencapai kesuksesan pembelajaran. Khususnya, pada siswa sekolah dasar sehingga siswa dapat memahami wacana atau bacaannya dengan lebih bermakna. Pembaca dapat menguasai bacaan dengan baik apabila mereka menguasai segi-segi kemampuan yang diperlukan dalam membaca. Ada dua faktor yang mempengaruhi keterampilan membaca pemahaman, yaitu faktor yang berasal dari dalam diri dan faktor yang berasal dari luar. Faktor-faktor yang berada dalam diri pembaca meliputi kemampuan linguistik (kebahasan), minat, motivasi, dan kumpulan kemampuan membaca (seberapa baik pembaca dapat membaca) (Zuchdi, 2000:23). Sementara, faktor-faktor di luar pembaca dibedakan menjadi dua kategori yaitu unsur-unsur bacaan dan lingkungan membaca. Unsur-unsur bacaan meliputi kebahasan teks dan organisasi teks. Kualitas lingkungan membaca meliputi persiapan guru sebelum, pada saat, atau suasana umum penyelesaian tugas. Semua faktor ini tidak saling terpisah, tetapi saling berhubungan. Berdasarkan penjelasan tersebut tampak jelas bahwa faktor-faktor yang mempengaruhi kemampuan membaca seseorang pada hakikatnya tidaklah tunggal. Dasar penyusunan tes membaca pemahaman dalam penelitian ini berdasarkan pada taksonomi Burret.: 
a) Pemahaman Harfiah. Pemahaman harfiah memberikan tekanan pada pokok-pokok pikiran dan informasi yang secara gamblang diungkapkan dalam wacana.

b) Mereorganisasi. Menghendaki siswa menganalisis, mensintesis, dan mengorganisasikan pikiran atau informasi yang dikemukakan secara eksplisit didalam wacana. Pada tingkat ini dapat dilakukan dengan memparafrasekan atau menterjemahkan ucapan-ucapan penulis

c) Pemahaman Inferensial. Pemahaman yang ditunjukkan oleh siswa apabila ia menggunakan hasil pemikiran atau informasi secara gamblang dikemukakan dalam wacana, intuisi, dan pengalaman pribadinya. Pada umumnya dirancang berdasarkan pertanyaan-pertnyaan yang menghendaki pemikiran dan imajinasi siswa.

d) Evaluasi. Tujuan membaca dan pertanyaan guru dalam hal ini adalah meminta respon siswa yang menunjukkan bahwa ia telah mengadakan tinjauan evaluasi dengan membandingkan buah pikiran yang disajikan di dalam wacana dengan kriteria luar yang berasal dari pengalaman pengetahuan atau nilai-nilai dari siswa.

e) Apresiasi. Apresiasi melibatkan seluruh dimensi kognitif yang telah disebutkan sebelumnya, karena apresiasi berhubungan dengan dampak psikologis dan estetis terhadap pembaca. Apresiasi menghendaki supaya pembaca secara emosional dan estetis peka terhadap suatu karya dan memintanya bereaksi terhadap nilai dan kekayaan unsurunsur psikologis dan artistik yang ada dalam karya itu. Apresiasi ini mencakup pengetahuan tentang respon emosional terhadap teknik-teknik, bentuk-bentuk, gaya serta struktur sastra.

Pemilihan tes membaca pemahaman menggunakan Taksnomi Burret. Takonomi ini untuk mengukur keterampilan membaca pemahaman siswa, karena dalam teori ini mengelompokkan tingkatan pemahaman mulai dari pemahaman sederhana hingga pemahaman yang sulit. Jenjang pemahaman yang bertahap, memudahkan peneliti untuk menyusun media dan rencana pelaksanaan pembelajaran.

\section{Komik Sebagai Media Pembelajaran}

Media pembelajaran merupakan sarana yang digunakan sebagai perantara penyalur informasi pesan berupa materi ajar antara guru dan siswa, yang diharapkan dapat menentukan berhasil atau tidaknya proses pendidikan. Media pembelajaran memiliki banyak manfaat. Namun faktanya, di sekolah masih terdapat proses pembelajaran yang dilakukan tanpa menggunakan media. Hal tersebut memberikan pemikiran baru bagi peneliti untuk mengembangkan media pembelajaran yang efektif sehingga dapat digunakan oleh siswa dan guru untuk meningkatkan keterampilan membaca pemahaman pada mata pelajaran bahasa Indonesia. Adapun media tersebut adalah komik.

Komik menurut Scott Mc Cloud dalam buku Understanding Comics: The Invisible Art, 1993 dalam MS. Gumelar (2011:6) yaitu juxtaposed pictorial and other images in deliberate sequence, intended convey information and/or produce an aesthetic response in the reader. McCloud (1993) menekankan bahwa komik adalah gambar berjajar dalam urutan yang disengaja, dimaksudkan untuk menyampaikan informasi atau menghasilkan respons estetik dari pembaca. MS. Gumelar (2011:7) dalam bukunya juga menjelaskan bahwa komik adalah urutan gambar yang ditata sesuai tujuan dan filosofi pembuatnya hingga pesan cerita tersampaikan, komik cenderung diberi leetering yang diperlukan sesuai dengan kebutuhan. Komik didefinisikan sebagai bentuk kartun yang mengungkapkan karakter dan menerapkan suatu cerita dalam urutan yang erat hubungannya dengan gambar dan dirancang untuk memberikan hiburan kepada para pembaca (Daryanto, 2011:127). Selain itu, Sujana dan Rivai (1991:65) berpendapat bahwa "komik adalah media yang popular pada abad ke-20, dan termasuk media yang sudah lama, namun demikian hingga saat ini komik masih banyak digemari terutama bagi kalangan remaja". Oleh sebab itu, jika 
dijadikan suatu media pembelajaran, kepopuleran komik dapat menjadi alat untuk menarik perhatian siswa.

Berdasarkan beberapa pengertian tersebut dapat disimpulkan bahwa komik merupakan kumpulan gambar yang terdiri dari urutan-urutan tertentu, dan tokoh yang memiliki karakter dalam sebuah rangkaian cerita yang memberikan unsur hiburan dalam penyampaiannya. Kita dapat belajar banyak dalam komik yaitu belajar mambaca, memahami cerita dengan cara visualisasi dan mengenal warna. Komik yang sering kita temukan adalah komik-komik yang bercerita superhero, cerita kartun dan legenda yang pada dasarnya hanya bersifat. Akan tetapi komik pun dapat digunakan sebagai media pembelajaran karena komik dapat dirancang sesuai dengan materi ajar yang akan disampaikan. Dalam hal ini komik berfungsi sebagai penyampai pesan pembelajaran dengan media visual yang dikemas semenarik mungkin agar siswa lebih tertarik untuk belajar. Biasanya komik sangat digemari oleh orang-orang yang mempunyai tipe belajar visual karena dalam komik suatu cerita disampaikan dengan dominasi gambar yang sangat menonjol.

Komik sesungguhnya lebih dari sekedar cerita bergambar yang ringan dan menghibur. Pernyataan ini sesuai dengan pendapat yang dikemukakan Rohani, (1997:21) yang menyatakan bahwa komik merupakan bentuk media komunikasi visual yang mempunyai kekuatan untuk menyampaikan informasi secara popular dan mudah dimengerti. Hal ini dimungkinkan karena komik memadukan kekuatan gambar dan tulisan, yang dirangkai dalam suatu alur cerita gambar membuat informasi lebih mudah diserap. Teks membuatnya lebih dimengerti, dan alur membuatnya lebih mudah untuk diikuti dan diingat. Media komik merupakan media yang mempunyai sifat sederhana, jelas, mudah dipahami dan lebih bersifat personal sehingga bersifat informatif dan edukatif. Hal senada juga disampaikan oleh Wurianto (2009:51) yang menyatakan bahwa komik sebagai media pembelajaran merupakan alat yang berfungsi untuk menyampaikan pesan pembelajaran. Dalam konteks ini pembelajaran menunjuk pada sebuah proses komunikasi antara siswa dan sumber belajar. Komunikasi belajar akan berjalan dengan maksimal jika pesan pembelajaran disampaikan secara jelas, runtut, dan menarik. Artinya, komik pembelajaran merupakan media yang dapat digunakan untuk mengatasi permasalahan dalam memahami suatu materi. Penggunaan analogi dan penggambaran cerita dalam kehidupan sehari-hari dapat membantu siswa untuk memahami suatu materi. Objek-objek yang terlalu kecil, terlalu besar, berbahaya atau bahkan tidak dapat dikunjungi oleh siswa dapat dihadirkan melalui media komik. Bukan hanya itu, komik pun dapat menarik semangat siswa untuk belajar dan mengajari siswa untuk menerjamahkan cerita ke dalam gambar bahkan seolah-seolah siswa dihadapkan pada konteks yang nyata sehingga muncul efek yang membekas pada siswa dan dapat mengingat sesuatu lebih lama. Materi yang terdapat di dalam komik dapat dijelaskan secara sungguhsungguh, yang artinya bahwa materi yang berbentuk gambar akan dapat menjelaskan keseluruhan cerita sehingga mempermudah siswa mengetahui bentuk konkret apa maksud dari materi tersebut.

Komik juga membantu untuk membangkitkan minat baca siswa. Suprana (2009) mengaku kalau minat bacanya tumbuh akibat membaca komik semasa kecilnya. Sejumlah komik menghadirkan nilai-nilai moral yang penting dikenal oleh siapa saja. Sebut saja nilai persahabatan, kerja keras, kebersamaan, kegigihan dan semangat pantang menyerah. Tidak semua hal yang kelihatannya baik itu baik dan mendatangkan manfaat. Komik sebagai media pembelajaran juga tidak terlepas dari kelemahan. Salah satu kelemahan komik adalah tidak semua orang bisa belajar efektif dengan gaya visual, karena setiap orang mempunyai gaya belajar masing-masing. Oleh karena itu komik tidak dapat selalu dijadikan media pembelajaran. Komik juga dapat membuat siswa menjadi malas karena ada juga siswa yang cenderung hanya ingin melihat gambar yang menarik menurut siswa tersebut, tidak memahami materi secara utuh. Bahkan enggan untuk membaca keseluruhan cerita sehingga daya serap terhadap materi rendah. Terkadang komik yang terjual di pasaran atau di toko buku terdapat gaya bahasa yang kotor dan terlalu khayal sehingga pesan atau materi yang disampaikan tidak mengenai target sasaran dan terjadi kesalahan presepsi. Banyak aksi-aksi yang menonjolkan kekerasan atau tingkah laku yang sinting dan sulit diterima 
oleh akal sehat atau kurang logis, sehingga siswa hanya hanyut dengan cerita khayal yang terdapat dalam komik tanpa ada kesan materi atau pesan yang disampaikan tidak dapat dicerna oleh siswa. Sering juga kita temui banyak komik yang hanya terdapat cerita-cerita cinta yang tidak bemanfaat untuk kemajuan intelektualitas siswa. Banyak orang yang mengatakan bahwa komik telah berperan dalam menciptakan kenakalan remaja. Sementara yang lain percaya bahwa komik meracuni minat baca dan imajinasi anak (Dorrell, Curtis, \& Rampal, 1995).

Adapun kekurangan komik yang lainnya adalah terlalu banyak mengonsumsi komik bisa mengumpulkan imajinasi pembaca. Perhatikanlah prosa, seperti novel atau cerpen yang banyak menggambarkan wajah tokoh tertentu dengan kata-kata daripada gambar. Pembaca diajak untuk membayangkan seperti apa wajah tokoh tersebut. Aspek-aspek inilah yang dalam komik diterjemahkan dalam gambar dan membuat pembaca langsung menikmatinya, tanpa harus membayangkan penggambaran tersebut lewat pikirannya. Mula-mula, imajinasi hanya terbatas pada apa yang digambarkan. Namun akhirnya, imajinasi bisa tumpul. Misalnya, hanya bisa membayangkan latar tempat sebagaimana digambarkan pada komik atau hanya bisa menggambar tokoh-tokoh seperti yang digambarkan oleh komikus terkait.

Komik terdiri dari tiga kelompok besar berdasarkan age segmentation pembaca (Gumelar, 2011:54), yaitu Children story, Teen story dan Adult story. Media komik untuk meningkatkan keterampilan membaca pemahaman dalam penelitian ini dibuat dengan segmentasi children story. Terlihat dari pembuatan karakter khas dunia anak-anak, bermakna edukatif, dan mengandung unsur pendidikan karakter. Gaya ini sangat sesuai untuk segmentasi pembaca usia SD. Hal ini karena cerita yang digunakan berasal dari kehidupan sehari-hari siswa. Alur cerita juga dibuat sederhana sehingga tidak membingungkan pembaca. Pemanfaatan komik bisa disesuaikan dalam berbagai konteks tujuan, tidak terkecuali dalam dunia pendidikan sebagai media pembelajaran. Komik dalam pembelajaran tentu harus dipilih yang mengandung unsur pendidikan sekaligus mengandung unsur hiburan.

Media komik yang dibuat memiliki fungsi atensi, afektif, kognitif, dan fungsi kompensatoris. Gambar dan alur cerita disajikan secara menarik sehingga akan membuat siswa tertarik untuk belajar. Siswa akan berusaha untuk mengikuti alur cerita dengan melihat gambar kemudian berusaha untuk menumbuhkan keterampilan membaca pemahaman pada cerita dalam komik. Pembelajaran menjadi lebih bermakna dengan adanya media komik, sehingga informasi yang diperoleh siswa akan bertahan lebih lama. Siswa yang memiliki kesulitan untuk memahami informasi verbal dari guru juga akan lebih terbantu dengan adanya media komik, selain itu media komik dapat digunakan oleh siswa untuk secara mandiri, baik di sekolah maupun di rumah. Berdasarkan penelitian yang relevan, media komik dapat menambah minat siswa dalam belajar, memudahkan siswa dalam memahami suatu bacaan, dan menambah variasi penggunaan media dalam proses pembelajaran. Media yang dikembangkan adalah media berbentuk komik. Alur yang runtut dan teratur serta cerita yang sederhana dalam komik, diharapkan mampu mempermudah siswa dalam memahami bacaan sehingga keterampilan membaca pemahaman pun meningkat.

\section{Metode Penelitian}

Penelitian ini termasuk dalam model Research and Development (R\&D). Penelitian dan Pengembangan adalah suatu proses atau langkah-langkah untuk mengembangkan suatu produk atau menyempurnakan produk yang telah ada, yang dapat dipertanggungjawabkan (Sukmadinata, 2013:164). Hasil dari penelitian ini berupa produk media pembelajaran komik untuk meningkatkan keterampilan membaca pemahaman pada mata pelajaran bahasa Indonesia. Penelitian dilakukan di kelas IV SDN 41 Pekanbaru. Produk yang dikembangkan dilakukan berdasarkan prosedur ADDIE. Objek dalam penelitian ini adalah media pembelajaran komik untuk meningkatkan keterampilan membaca pemahaman pada mata pelajaran bahasa Indonesia.

Ada dua macam teknik pengumpulan data yang digunakan dalam penelitian ini yaitu tehnik test dan non test. Untuk instrumen yang digunakan dalam penelitian ini berupa lembar pedoman observasi, angket ahli media, angket untuk ahli materi, angket untuk siswa, dan angket keterampilan membaca pemahaman,. Pengujian instrumen dilakukan dengan menggunakan 
validitas isi, yakni dengan membandingkan isi instrumen dengan teori yang ada. Instrumen dalam penelitian ini adalah tes unjuk kerja membaca pemahaman. Selanjutnya untuk uji reliabilitas yang digunakan untuk menguji kehandalan tes unjuk kerja membaca pemahaman adalah melalui reliabilitas antar-rater ( interater reliability). Analisis data adalah pengolahan data yang diperoleh dengan menggunakan rumus-rumus atau aturan-aturan yang ada sesuai dengan pendekatan penelitian atau desain yang diambil (Arikunto, 2002:236). Analisis data dilakukan dengan teknik analisis kualitatif dan analisis kuantitatif guna menjawab rumusan masalah penelitian.

\section{Hasil dan Pembahasan}

Prosedur pengembangan media komik menggunakan model pengembangan ADDIE yang terdiri dari lima tahap:

a. Analysis

Produk yang sesuai dikembangkan sebagai media untuk meningkatkan keterampilan membaca pemahaman adalah komik. Media komik merupakan susunan ilustrasi-ilustrasi gambar yang menerangkan suatu cerita dan memberikan hiburan kepada pembaca. Isi cerita dari komik disesuaikan dengan kebutuhan siswa dan tujuan pembelajaran, yaitu untuk meningkatkan keterampilan membaca pemahaman. Komik dapat menjadi media yang tepat untuk meningkatkan keterampilan membaca pemahaman pada materi membaca cerita anak yang diilustrasikan , sehingga menjadi lebih menarik. Demikian siswa akan lebih mudah memahami isi cerita dengan lebih menyenangkan, sehingga keterampilan membaca pemahaman siswa akan meningkat.

\section{b. Design}

Peneliti merancang konsep yang akan dimuat dalam komik, kemudian mengumpulkan materi yang berkaitan dengan membaca pemahaman sesuai dengan silabus pembelajaran di SD Negeri Bener 1 Kabupaten kemudian disusun. Membuat ringkasan cerita atau prolog untuk menerukan jumlah tokoh serta karakternya. Ringkasan cerita tersebut kemudian digunakan untuk menyusun alur cerita dan pembuatan ilustrasi gambar. Isi cerita disesuaikan dengan materi membaca cerita anak yang telah disusun. Pembuatan ilustrasi dilakukan menggunakan dua aplikasi yang berbeda autodesk sketchbook android untuk membuat ilustrasi gambar dengan komponen ruang panel, balon kata, latar tempat, ekspresi tokoh dan Adobe Photoshop CS5 untuk editing teks pada komik. Pembuatan gambar dilakukan berdasarkan storyline.

Media komik memuat sampul depan komik, salinan sampul depan, daftar isi, petunjuk pengguanaan, indikator pembelajaran, karakter tokoh, sampul cerita pertama, cerita pertama, amanat cerita, soal postest, sampul cerita pertama, cerita pertama, amanat cerita pertama, soal postest pertama , sampul cerita kedua, cerita kedua, amanat cerita kedua, soal postest kedua , sampul cerita ketiga, cerita ketiga, amanat cerita ketiga, soal postest ketiga, sampul cerita keempat, cerita keempat, amanat cerita keempat, soal postest keempat, sampul cerita kelima, cerita kelima, amanat cerita kelima, soal postest kelima, profil pengembang, sampul belakang komik beserta prolognya. Komik terdiri 46 halaman, di setiap halaman terdapat materi membaca cerita anak yang mengandung unsur pendidikan karakter. Konsep yang telah dirancang secara matang, kemudian disusun untuk dijadikan produk komik yang berbentuk buku.

\section{c. Development}

Media komik yang telah dicetak kemudian diuji kelayakannya oleh ahli materi dan ahli media. Ahli materi adalah dosen prodi Pendidikan Guru Sekolah Dasar Fakultas Ilmu Pendidikan Universitas Negeri Yogyakarta kompetensi bidang mata pelajaran bahasa Indonesia SD. Ahli media adalah dosen Teknologi Pendidikan Fakultas Ilmu Pendidikan Universitas Negeri Yogyakarta yang memiliki kompetensi di bidangnya. Hasil penilaian kelayakan media komik oleh ahli materi 
memperoleh rata-rata skor sebesar 4,59 yang termasuk dalam kategori sangat layak. Ahli media memperoleh rata-rata skor sebesar 4,68 yang termasuk dalam kategori sangat layak. Kesimpulan dari penilaian media tersebut adalah bahwa media komik layak digunakan dalam proses pembelajaran, dikatakan layak karena semua aspek penilaian sudah dapat terpenuhi.

\section{d. Implementation}

Tahap implementasi dilakukan oleh praktisi pembelajaran yaitu guru kelas IV SDN 41 Pekanbaru dan siswa kelas IV SDN 41 Pekanbaru sejumlah 17 orang, karena peneliti ingin mengetahui penilaian respon media dari guru dan siswa selaku sebagai komik. Implementasi terdiri dari tiga tahap, yaitu: 1) uji coba awal, oleh dua siswa dengan tingkat prestasi berbeda; 2) uji coba utama, oleh enam siswa dengan tingkat prestasi berbeda; dan 3) uji coba lapangan operasional. oleh seluruh siswa kelas IV. Guru membantu peneliti dalam mengawasi dan mengarahkan jalannya pembelajaran, sehingga implementasi media komik dapat berjalan dengan efektif dan efisien.

Hasil penilaian respon media komik oleh siswa pada uji coba awal memperoleh rata-rata skor sebesar 4,20 yang termasuk dalam kategori sangat layak. Siswa pada uji coba utama memperoleh rata-rata skor sebesar 4,32 yang termasuk dalam kategori sangat layak. Siswa pada uji coba lapangan operasional memperoleh rata-rata skor sebesar 4,43. Guru memberikan respon pada media komik memperoleh rata-rata skor sebesar 4,68 untuk aspek materi dan 4,80 untuk aspek media yang termsuk dalam kategori sangat layak. Sesuai hasil angket respon yang mendapatkan rata-rata skor sangat layak, tidak heran bahwa siswa terlihat sangat antusias dalam pembelajaran menggunakan komik. Selama pembelajaran, mereka memahami isi cerita yang tersaji dalam komik dengan seksama. Pembelajaran menggunakan media komik ini membawa suasana baru dalam belajar yaitu dengan menggunakan media, dengan demikian siswa tertarik untuk membaca dan mudah dalam memahami isi cerita anak. Media komik membuat pembelajaran lebih menyenangkan dan tidak menjadi beban.

\section{e. Evaluate}

Tujuan utama dari pengembangan media komik ini adalah untuk meningkatkan keterampilan membaca pemahaman pada mata pelajaran bahasa Indonesia kelas IV. Berdasarkan hasil penelitian, media komik dapat meningkatkan keterampilan membaca pemahaman dalam kategori sedang, yaitu berdasarkan perbandingan hasil pretest (sebelum menggunakan media komik) dan hasil postest (setelah menggunakan media komik). yang dianalisis menggunakan uji gain score adalah 0,376 dimana angka tersebut berada pada rentang 0,3 dan 0,7 yang termasuk dalam kategori sedang. Pada tahap ini, dapat disimpulkan bahwa pengembangan media komik ini efektif digunakan dalam pembelajaran karena dapat meningkatkan keterampilan membaca pemahaman.

Media komik belum dapat dikatakan layak untuk digunakan apabila belum dilakukan penilaian oleh ahli materi, ahli media, praktisi pembelajaran (guru dan siswa). Hal ini sejalan dengan penjelasan (Arsyad, 2003:175) bahwa perlu adanya penilaian sebelum media komik digunakan dengan kriteria penilaian dari ahli materi ahli media, dan praktisi pembelajaran. Ahli materi, ahli media dan praktisi pembelajaran masing-masing menilai aspek pada angket penilaian media dan respon media dengan kategori minimal layak. Hasil penilaian kelayakan media komik oleh ahli materi dapat dilihat pada tabel 12, penilaian oleh ahli media dapat dilihat pada tabel 15, penilaian respon terhadap media komik tertera pada tabel 18 hingga tabel 33. Penjelasan selengkapnya adalah: 
a) Ahli Materi. Berdasarkan penilaian ahli materi, media komik mendapatkan nilai rata-rata skor 4,56. Hal ini menunjukkan bahwa media komik masuk dalam kategori "Sangat Layak" dan mendapatkan nilai "A", berdasarkan hasil tersebut, dapat dipaparkan bahwa media komik "Sangat Layak" karena dapat diimplementasikan dalam kegiatan belajar mengajar yang mengukur hasil membaca keterampilan membaca pemahaman ditinjau dari aspek materi, pembelajaran, dan membaca pemahaman. Kelayakan materi ditinjau dari 21 butir pernyataan yang terdiri dari 7 butir pernyataan aspek pembelajaran, 8 butir aspek materi dan 6 butir aspek membaca pemahaman. Hasil penilaian dari ahli materi menunjukkan bahwa aspek pembelajaran, aspek materi, dan aspek membaca pemahaman sangat layak. Aspek pembelajaran memperoleh rata-rata 4,57, aspek materi memperoleh rata-tara 4,62, dan aspek membaca pemahaman meperoleh rata-rata 4,5.

b) Ahli Media. Berdasarkan penilaian ahli materi, media komik mendapatkan nilai rata-rata skor 4,59. Hal ini menunjukkan bahwa media komik masuk dalam kategori "Sangat Layak" dan mendapatkan nilai "A", karena dapat diimplementasikan dalam kegiatan belajar mengajar ditinjau dari aspek tampilan, bahan, dan pembelajaran. Kelayakan media ditinjau dari 19 butir pernyataan yang terdiri dari 13 butir pernyataan aspek tampilan, 3 butir aspek bahan dan 3 butir aspek pembelajaran. Hasil penilaian dari ahli media menunjukkan bahwa aspek tampilan , aspek bahan, dan aspek pembelajaran sangat layak. Aspek tampilan memperoleh rata-rata 4,46, aspek bahan memperoleh rata-rata 5 , dan aspek pembelajaran meperoleh rata-rata 4,33.

c) Praktisi Pembelajaran (Guru dan Siswa). Berdasarkan penilaian respon guru, media komik memperoleh rata-rata skor 4,68 untuk aspek materi dan 4,80 untuk aspek media. Sehingga mendapatkan nilai "A", Selanjutnya, berdasarkan penilaian respon siswa terhadap komik pada uji coba awal memperoleh rata-rata skor 4,2, uji coba utama memperoleh rata-rata skor 4,32, uji coba lapangan operasional memperoleh rata-rata skor 4,43 dan mendapatkan nilai " $A$ " berdasarkan hasil tersebut, dapat dikatakan media pembelajaran "Sangat Layak" karena dapat diimplementasikan dalam pembelajaran bahasa Indonesia.

Guna mengetahui media komik dapat meningkatkan keterampilan membaca pemahaman siswa, digunakan soal pretest dan postest. Sesuai tabulasi data. diketahui jumlah skor rata-rata nilai pretest sebesar 53,82, kemudian mengalami peningkatan pada skor rata-rata nilai postest sebesar 17,38 menjadi 71,20. Perhitungan hasil peningkatan keterampilan membaca pemahaman siswa menggunakan Gain Score sebesar 0,376. Hasil perhitungan menunjukkan peningkatan keterampilan membaca pemahaman siswa termasuk dalam kategori peningkatan sedang. Disamping itu, peserta didik sangat antusias sekali dalam proses pembelajaran menggunakan media komik yang telah dikembangkan oleh penulis. Hal tersebut nampak terlihat dari ekspresi dan sikap peserta didik dalam proses pembelajaran menggunakan media komik ini. Beberapa peserta didik juga ada yang meninggalkan komentar di angket penilaian yang telah diberikan oleh penulis, hasildari komentar peserta didik menunjukan tanggapan positif yang diberikan kepada penulis. Peserta didik sangat menyukai media pembelajaran berbasis komik ini karena dengan adanya media komik proses pembelajaran dapat lebih menyenangkan.

Media akhir dari penelitian ini berupa komik untuk meningkatkan keterampilan membaca pemahaman siswa kelas IV SD. Komik disajikan dalam tampilan menarik sehingga siswa tertarik untuk belajar memahami bacaan dengan mudah. Pada dasarnya kemampuan pemahaman membaca bagi siswa sekolah dasar adalah bagaimana mengupayakan agar siswa gemar membaca dan menulis. Oleh karena itu agar semakin tumbuhnya budaya baca di kalangan siswa, guru dituntut untuk selalu kreatif dalam menggunakan sumber-sumber belajar di kelas. Penggunaan komik yang diintegrasikan dengan materi dapat dimanfaatkan sebagai media untuk meningkatkan literasi membaca siswa. 
Jurnal Onoma: Pendidikan, Bahasa dan Sastra

\section{Simpulan}

berikut:

Hasil pengembangan media komik di SDN 41 Pekanbaru didapatkan kesimpulan sebagai

1. Pengembangan media komik pada penelitian ini telah memenuhi kriteria layak untuk meningkatkan keterampilan membaca pemahaman pada mata pelajaran bahasa Indonesia kelas IV karena dalam aspek tampilan media komik menggunakan desain komik yang menggunakan proporsi warna beragam, tulisan yang jelas, ilustrasi gambar yang terpadu, dan nyaman untuk digunakan serta pada aspek materi komik menonjolkan segementasi dunia anak-anak SD kelas tinggi, materi cerita yang sesuai dengan muatan pembelajaran, dan kalimat-kalimat yang berstruktur sederhana sehingga mudah dipahami siswa.

2. Media komik efektif digunakan untuk meningkatkan keterampilan membaca pemahaman pada mata pelajaran bahasa Indonesia berdasarkan hasil uji rata beda sebesar 0,037 dan uji nilai gain sebesar 0,376.

\section{Daftar Pustaka}

Ahmad Rohani. (1997). Media intruksional Edukatif. Jakarta: PT Rineka Cipta.

Dalman, (2013). Keterampilan Membaca. Jakarta: PT. Raja Grafindo Persada.

Daryanto. (2010). Media Pembelajaran, Peranannya Sangat Penting dalam Mencapai Tujuan

Pembelajaran. Yogyakarta.: Gava Media

Depdiknas. (2006). Kurikulum Tingkat Satuan Pendidikan. Jakarta: Depdiknas

Dorrell, L., Curtis, D., \& Rampal, K. (1995). Studens Reading Comic Books in TheSchool House. journal of Popular Culture, 223-234.

Farida Rahim. (2008). Pengajaran Membaca di Sekolah Dasar. Jakarta: Bumi Aksara.

Gumelar, M.S. (2004). Comic Making. Jakarta: PT. Indeks

Iskandar Wassid. (2004). Strategi Pembelajaran Bahasa. Bandung: Rosda Karya

McCloud, S. (2011). Understanding Comics, Memahami Komik. Jakarta: KPG

Merch, A. (2013). The Effect Of Comic Strips on Efl Reading Comprehension. Vol. 4 number 1, January

2013. Diambil dari: http://www.ijonte.org. (14 Agustus 2020)

Resmini, N, dkk. (2009). Pembinaan dan Pengembangan Pembelajaran Bahasa dan Sastra Indonesia. Bandung: UPI Press

Slamet. (2007). Dasar-dasar Pembelajaran Bahasa dan Sastra Indonesia di SD. Surakarta: UNS Press.

Sudjana, N., Rivai, A. (2009). Media Pengajaran. Bandung: Sinar Baru Algensindo

Sukmadinata, N.S. (2013). Metode Penelitian Pendidikan. Bandung: Rosdakarya

Suprana, J. (2009). Naskah-Naskah Kompas Jaya Suprana, Jakarta: Elex Media Komputindo.

Wurianto, E. (2009). Komik sebagai Media Pembelajaran. (www.powerpoint-search.com/mediapembelajaran-komik-ppt.html

Zuchdi, D. 2007. Strategi Meningkatkan Kemampuan Membaca. Yogyakarta: UNY Press 